\title{
Interaction between Marbofloxacin and Flunixin in Treatment of Pneumonia in Lambs
}

\author{
Mohammed H. Khairy ${ }^{1}$, Abd El Alim F. Abd El Alim ${ }^{1 *}$, Ibrahim M Ismail ${ }^{2}$ and Mohamed E \\ Darwish $^{2}$ \\ ${ }^{1}$ Pharmacology Department, Faculty of Veterinary Medicine, Zagazig University, 44511, Egypt \\ ${ }^{2}$ Animal Health Research Institute, Zagazig branch, Egypt
}

\begin{abstract}
Nasopharyngeal swabs were collected from 100 lambs aging $9-12$ months (30 healthy and 70 pneumonic lambs for bacteriological examination. Overall, $25 \%$ were positive for $P$ multocida. Antibiogram study of the isolates revealed that marbofloxacin was the highest effective against P. multocida. Forty lambs (20 healthy and 20 naturally infected with $P$ multocida) were divided into 8 groups $\left(5\right.$, each), the $1^{\text {st }}$ group: healthy lambs (control), $2^{\text {nd }}$ group: healthy received marbofloxacin, $3^{\text {rd }}$ group: healthy received flunixin meglumine, $4^{\text {th }}$ group: healthy received marbofloxacin and flunixin meglumine together, $5^{\text {th }}$ group: infected non treated, $6^{\text {th }}$ group: infected treated with marbofloxacin, $7^{\text {th }}$ group: infected treated with flunixin meglumine and $8^{\text {th }}$ : group infected treated with marbofloxacin and flunixin meglumine together. Hematobiochemical changes at $1^{\text {st }}, 7^{\text {th }}$ and $14^{\text {th }}$ day post treatment were studied. All clinical sign disappeared and P.multocida microorganisms were not reisolated in group post treated by marbofloxacin alone or together with flunixin meglumine. Healthy lambs received marbofloxacin or flunixin meglumine either alone or together showed significant decrease in RBCs, $\mathrm{Hb}, \mathrm{PCV} \%$, $\mathrm{T}$ protein, albumin, globulin, $\alpha, \beta, \gamma$ globulin and significant increase in WBCs, AST, ALT, ALP, GGT, urea and creatinine at ${ }^{\text {st }}$ and $7^{\text {th }}$ day post injection. Pneumonic lambs showed significant reduction in RBCs, $\mathrm{Hb}, \mathrm{PCV} \% \mathrm{~T}$. protein, albumin, total globulin, $\alpha, \beta$ globulin and significant increase in WBCs, AST, ALT, ALP, GGT, $\gamma$ globulin, urea and creatinine all over the experimental period. Pneumonic lamb treated with marbofloxacin alone or with flunixin meglumine resulted in complete disappearance of these clinical signs at $1^{\text {st }}$ day post treatment but these clinical signs remained in flunixin meglumine alone lambs. It is concluded that, pasteurellosis in lambs resulted in adverse effect in hematobiochemical parameters. Using marbofloxacin alone or together with flunixin meglumine in treatment of diseased lambs lead to improve clinical signs and hemato-biochemical parameters at $7^{\text {th }}$ day post treatment.
\end{abstract}

Keywords: Marbofloxacin, Flunixin, Treatment, Pneumonia, Lambs

\section{Introduction}

Respiratory infections represent in diseases lambs cause high economic losses. Pneumonic pasteurellosis is one of the most economically infectious diseases of lambs with a wide prevalence throughout the continents [1]. Pasteurella multocida comprises 5 capsular serogroups and 16 somatic serotypes [2]. Many efforts were done for controlling and prevent disease through medication, so continuous research for new drugs for controlling the disease is a necessity [3]. Marbofloxacin is a $3^{\text {rd }}$ generation synthetic bactericidal drug belonging to fluoroquinolones acts by inhibition of DNA gyrase. It is effective against a wide range of $\mathrm{Gr}+\mathrm{ve} \&$ Gr-ve bacteria as pasteurella multocida [4]. It is used for treatment of respiratory and urinary diseases [5].
Flunixin meglumine is a member of non steroidal antiinflammatory drugs inhibit is production of body prostaglandins and other chemicals stimulate bodys inflammatory response. Flunixin meglumine works quickly, with pain relief and fever reduction starting within one to two hours [9].

The present study was carried out to evaluate the effect of marbofloxacin, flunixin meglumine and their combination on healthy and pneumonic lambs caused by pasteurella multocida beside study the effects of pasteurella multocida and drugs on some hemato-biochrmical parameters in lambs. 
Material and Methods

\section{Drugs}

Marbofloxacin $10 \% \quad(\text { Marbocyl } 10 \%)^{\mathrm{R}}$ produced byVetoquinol S.A., (france) is a synthetic broad spectrum antibacterial agent from the flouroquinolone class of chemotherapeutic agents. Flunixin meglumine (Finadyne $^{\circledR}$ ) is a product of Schering-Plough animal health Segre -France.

\section{Isolation and identification}

A total of 100 Nasopharyngeal swabs (30 apparently healthy lambs and 70 pneumonic lambs showed clinical sign as fever, bilateral nasal discharg, congested mucous membranes, moist cough, abnormal respiratory sounds, dyspnea and recombency) 9 -12 month old were obtained from private farms at Abou Hamad city, Sharkia Governorate. All samples were collected aseptically and inoculated into nutrient broth aerobically at $37^{\circ} \mathrm{C}$ over night, subculturing on nutrient agar and MacConkey agar plates was performed for $24 \mathrm{~h}$ at $37^{\circ} \mathrm{C}$, colonies were identified [6]. Pathogenicity and virulence of isolated $P$. multocida to mice [7].

\section{Antibiotic sensitivity test}

Susceptibility of $P$. multocida to different chemotherapeutic agents was tested by disc diffusion method [8].

\section{Experimental lambs}

forty lambs aged from $9-12$ month old at a prived farm in Abou Hamad city, Sharkia Governorate were involved in this investigation (20 clinicaly healthy and 20 pneumonic lambs). Lambs were reared under hygienic measures feed on barseem and dry ration and water was supplied ad libitum. Pneumonic lambs showed clinical sign include fever, congested mucous membranes, bilateral nasal discharg, moist cough, dyspnea, abnormal respiratory sounds and recumbency.

\section{Experimental design}

Lambs were classified into 8 equal groups (5 Lambs in each), $1^{\text {st }}$ group healthy lamb non treated (control), $2^{\text {nd }}$ group healthy lamb received $10 \mathrm{mg} / \mathrm{kgm}$ b.wt. marbofloxacn [9] $3^{\text {rd }}$ group healthy lamb received $1.1 \mathrm{mg} / \mathrm{kgm}$ bwt flunixin meglumine [10], $4^{\text {th }}$ group healthy lamb received marbofloxacin and flunixin meglumine together by same dose. $5^{\text {th }}$ group infected lambs with pasteurella multocida non treated. $6^{\text {th }}$ group infected lambs treated by marbofloxacin by same dose, $7^{\text {th }}$ group infected lambs treated by flunixin meglumine by same dose and the $8^{\text {th }}$ group infected lambs treated with marbofloxacin and flunixin meglumine together by same dose. Treatment was $\mathrm{I} / \mathrm{M}$ in all groups for 5 consecutive days.

\section{Sampling}

Two blood samples were taken from all lambs from jugular vein on $1^{\text {st }}, 7^{\text {th }} \& 14^{\text {th }}$ days post injection. The first sample was collected in test tube contain EDTA for estimation hemogram and total leukocytic count according to [11]. While, the second sample was collected in centrifuge tubes and serum was separated for measuring total proteins [12]. Protein fractions were performed using cellulose acetate electrophoresis test [13], estimation of aspartate aminotransferas (AST), alanine aminotransferas (ALT) [14], Gamma glutamyl transferase (GGT) [15], alkaline phosphatase (ALP) [16], urea [17], creatinine [18].

\section{Reisolation of Pasterulla multocida}

Nasopharyngeal swabs were taken aseptically from all groups post treatment then inoculated into nutrient broth aerobicaly at $37^{\circ} \mathrm{C}$ over night followed subculturing on selective media for $24 \mathrm{~h}$ at $37^{\circ} \mathrm{C}$, suspected colonies were identified according to colonial morphology, microscopically by gram's stain and biochemically [6].

Statistical analysis: obtained data were analyzed [19].

\section{Results and Discussion}

Bacteriological examination of nasopharyngeal swabs from pneumonic lambs revealed the predominant isolates were pasteurella multocida, Streptococcal spp, E. coli and mixed infection. Similar pathogens were isolated from pneumonic lambs [20]. Also, Morad et al., [21] isolate pasteurella multocida from pneumonic different animals. These results are agreed with these obtained by El-Dahshan and Elham [22] isolate pasteurella multocida and E. coli from pneumonic sheep.

The present study by using the discdiffusion test showed that marbofloxacin was 
the highest effective on $P$. multocida than other tested drugs. These results are agreed with Valle et al., [23] who stated that marbofloxacin was very active against bovine respiratory tract pathogen as Pasteurella multocida. Also, our results coincide with those obtained by Thomas et al., [4] they recorded that marbofloxacin has been approved for treatment of respiratory disease in cattle, pigs, dogs, and cats. Pneumonic lambs showed clinical signs as fever, bilateral nasal discharge, congested mucous membranes, moist cough, dyspnea and recombency. Typical clinical signs were recorded by Zeitoun [24] in pneumonic sheep, Hussein et al., [25] in pneumonic lamb, Ali et al., [26] in Friesian calves. These signs may be due to bacterial infections and its toxins [27].

Table 1: Types and percentage of isolated bacterial spp. from collected nasopharyngeal swabs in lambs

\begin{tabular}{|c|c|c|c|c|c|}
\hline \multirow{2}{*}{\multicolumn{2}{|c|}{$\begin{array}{l}\text { Total number of nasopharyngeal } \\
\text { swabs }\end{array}$}} & \multirow{2}{*}{$\begin{array}{c}\text { Types of isolated } \\
\text { bacteria }\end{array}$} & \multicolumn{3}{|c|}{ bacterial isolate } \\
\hline & & & -ve & $+v e$ & $\%$ \\
\hline Healthy lambs & 30 & & -- & -- & $\begin{array}{ll}--- \\
\end{array}$ \\
\hline \multirow[t]{4}{*}{ Diseased lambs } & & Pasteurella multocida & & 25 & $25 \%$ \\
\hline & 70 & Stereptococcal spp & --- & 10 & $10 \%$ \\
\hline & & E. coli & --- & 9 & $9 \%$ \\
\hline & & Mixed infection & --- & 9 & $9 \%$ \\
\hline
\end{tabular}

The present investigation revealed that significant healthy lambs received marbofloxacin and flunixin meglumine either alone or together for 5 consecutive days displayed significant decrease in RBCs, HB and PCV \% beside significant leukocytosis on $1^{\text {st }}$ and $7^{\text {th }}$ day post injection accompanied with insignificant effect in blood picture on $14^{\text {th }}$ day post injection when compared with non infected non treated lambs. This finding may be due to suppressive effect of fluoroquinolones on growth and differentiation of hematopoietic cells like erythroid precursors [28]. Also, the present changes in blood picture may be attributed to deleterious effect of drug on bone marrow resulted in bone marrow dysfunctions [29]. Our results are compatible with Elmeleh [30] stated that marbofloxacin produced significant decrease in RBCs, $\mathrm{HB}$ and PCV \%. Our findings were in accordance with that of Carrick et al., [31] and McIlwraith et al., [32] they recorded that Flunixin induced significant decrease in RBCs, $\mathrm{HB}$ and PCV \% and leucocytosis.

Table 2: In-vitro susceptibility of pasterulla multocida to marbofloxacin and other commonly used antimicrobial agents by disc diffusion method.

\begin{tabular}{lcccc}
\hline Drug & Mark & (Potency (ug) & Standerd inhibition zone & $\begin{array}{c}\text { Mean Zone of } \\
\text { Inhibition(mm) }\end{array}$ \\
\hline Marbofloxacin & MAR & 5 & $\leq 20 \mathrm{~mm}$ & $25 \mathrm{~mm}$ \\
Florfenicol & FF & 30 & $\leq 18 \mathrm{~mm}$ & $20 \mathrm{~mm}$ \\
Doxycycline & DX & 30 & $\leq 14 \mathrm{~mm}$ & $19 \mathrm{~mm}$ \\
Streptmycin & $\mathrm{St}$ & 10 & $\leq 18 \mathrm{~mm}$ & $18 \mathrm{~mm}$ \\
Gentamycin & $\mathrm{Gm}$ & 10 & $\leq 15 \mathrm{~mm}$ & $15 \mathrm{~mm}$ \\
Neomycin & $\mathrm{NM}$ & 30 & $\leq 17 \mathrm{~mm}$ & $15 \mathrm{~mm}$ \\
Spectinomycin & $\mathrm{Sp}$ & 100 & $\leq 23 \mathrm{~mm}$ & $13 \mathrm{~mm}$ \\
\hline
\end{tabular}

The present work revealed that pneumonic lambs showed significant reduction in RBCs, $\mathrm{HB}, \mathrm{PCV} \%$ and significant increase in WBCs throughout the experimental period. Reduction in erythrogram parameters as a result to the Pasteurella multocida infection in lambs may be attributed to bacterial endotoxins which cause intravascular destruction of erythrocytic 
cells and consequently lead to hemolysis with breakdown of hemoglobin [33]. The change in blood picture in infected lambs come from Dagmar et al., [34] stated that infected bacteria produced cell damaging protein toxin (hemolysin) causes changes in cell membrane permeability and formation of surface lesions causes RBCs destruction. Such data go hand in hand with those reported by Salh and ElBably [35] in pneumonic sheep

Healthy lambs received marbofloxacin and flunixin meglumine either alone or together for 5 consecutive days showed the side effect of drugs resembles the effect of the disease significant increase in serum AST, ALT, GGT, ALP, urea and creatinine on $1^{\text {st }} \& 7^{\text {th }}$ day post treatment associated with insignificant increase on $14^{\text {th }}$ days post treatment. Our finding clearly confirmed by those obtained by Clark et al., [36] who reported that fluoroquinolones had hepatotoxic effect. Increase in liver enzymes, urea and creatinine may indicate a degenerative changes and hypofunction of liver and kidney [37]. Same changes in liver enzymes were reported by Novert [27] who stated that marbofloxacin induce of degeneration and necrosis of hepatocytes leading to elevation in AST, ALT and ALP in rats. Elevations in liver enzymes in our study may be due to alteration of membrane permeability or damage of hepatic cells by direct effect of the drugs resulting in escape of these enzymes to the plasma [38].

Table 3: Effect of marbofloxacin and flunixin meglumine on blood picture in healthy and pneumonic lambs $(\mathbf{n}=5)$

\begin{tabular}{|c|c|c|c|c|c|c|c|c|c|c|c|c|}
\hline \multirow{3}{*}{ Groups } & \multicolumn{9}{|c|}{ Erythrogram } & \multirow{2}{*}{\multicolumn{3}{|c|}{ T.LC (x 103/ ml) }} \\
\hline & \multicolumn{3}{|c|}{$\operatorname{RBCs}\left(\times 10^{6} / \mathrm{ml}\right)$} & \multicolumn{3}{|c|}{ Hb gm/dl } & \multicolumn{3}{|c|}{ PCV \% } & & & \\
\hline & $1^{\text {st }} d$ & $7^{\text {th }} d$ & $14^{\text {th }} \mathrm{d}$ & $\mathbf{1}^{\mathrm{st}} \mathrm{d}$ & $7^{\text {th }} d$ & $14^{\text {th }} \mathrm{d}$ & $\mathbf{1}^{\mathrm{st}} \mathrm{d}$ & $7^{\text {th }} \mathrm{d}$ & $14^{\text {th }} \mathrm{d}$ & $\mathbf{1}^{\mathrm{st}} \mathrm{d}$ & $7^{\text {th }} \mathrm{d}$ & $14^{\text {th }} \mathrm{d}$ \\
\hline \multirow{2}{*}{$\mathrm{Gp}(1)$} & $11.5 \pm$ & $11.53 \pm$ & $11.41 \pm$ & $9.53 \pm$ & $9.40 \pm$ & $9.66 \pm$ & $27.94 \pm$ & $27.88 \pm$ & $27.87 \pm$ & $9.47 \pm$ & $9.66 \pm$ & $9.46 \pm$ \\
\hline & 0.84 & 0.95 & 0.28 & 0.91 & 0.27 & 0.48 & 0.98 & 0.89 & 0.84 & 0.64 & 0.51 & 0.27 \\
\hline \multirow{2}{*}{$\mathrm{Gp}(2)$} & $7.96 \pm$ & $8.07 \pm$ & $9.90 \pm$ & $7.34 \pm$ & $8.16 \pm$ & $8.66 \pm$ & $24.09 \pm$ & $24.13 \pm$ & $26.16 \pm$ & $12.35 \pm$ & $11.04 \pm$ & $10.34 \pm$ \\
\hline & $0.98^{*}$ & $0.77 *$ & 0.94 & $0.40^{*}$ & $0.50 *$ & 0.69 & $0.83^{*}$ & $0.82 *$ & 0.85 & $0.86^{*}$ & $0.31^{*}$ & 0.83 \\
\hline \multirow{2}{*}{$\mathrm{Gp}(3)$} & $7.77 \pm$ & $8.90 \pm$ & $9.94 \pm$ & $6.06 \pm$ & $6.99 \pm$ & $8.99 \pm$ & $24.35 \pm$ & $24.43 \pm$ & $25.56 \pm$ & $12.56 \pm$ & $12.04 \pm$ & $10.60 \pm$ \\
\hline & $0.95^{*}$ & $0.60 *$ & 0.95 & $0.82 *$ & $0.80 *$ & 0.57 & $0.69^{*}$ & $0.82^{*}$ & 0.85 & $0.79 *$ & $0.63 *$ & 0.95 \\
\hline \multirow{2}{*}{$\mathrm{Gp}(4)$} & $7.85 \pm$ & $8.58 \pm$ & $9.85 \pm$ & $6.14 \pm$ & $7.05 \pm$ & $8.96 \pm$ & $23.49 \pm$ & $23.62 \pm$ & $25.86 \pm$ & $12.14 \pm$ & $12.44 \pm$ & $10.03 \pm$ \\
\hline & $0.78^{*}$ & $0.40 *$ & 0.97 & $0.88 *$ & $0.77 *$ & 0.47 & $0.98 *$ & $0.99 *$ & 0.95 & $0.92 *$ & $0.96 *$ & 0.65 \\
\hline \multirow{2}{*}{$\mathrm{Gp}(5)$} & $8.06 \pm$ & $8.65 \pm$ & $8.80 \pm$ & $6.03 \pm$ & $6.25 \pm$ & $6.23 \pm$ & $24.23 \pm$ & $24.16 \pm$ & $25.06 \pm$ & $12.84 \pm$ & $12.80 \pm$ & $12.90 \pm$ \\
\hline & $0.47 * *$ & $0.10 * *$ & $0.68 * *$ & $0.71 * *$ & $0.63 * *$ & $0.8 * *$ & $0.98 * *$ & $0.35 * *$ & $0.30 * *$ & $0.42 * *$ & $0.56^{* *}$ & $0.35^{* *}$ \\
\hline \multirow{2}{*}{$\mathrm{Gp}(6)$} & $8.54 \pm$ & $9.90 \pm$ & $10.29 \pm$ & $6.95 \pm$ & $7.89 \pm$ & $9.64 \pm$ & $24.06 \pm$ & $25.05 \pm$ & $26.21 \pm$ & $12.05 \pm$ & $10.02 \pm$ & $9.62 \pm$ \\
\hline & $0.57 *$ & 0.98 & 0.83 & $0.25^{*}$ & 0.96 & 0.56 & $0.70 *$ & $0.80 *$ & 0.99 & $0.82 *$ & 0.92 & 0.50 \\
\hline \multirow{2}{*}{$\mathrm{Gp}(7)$} & $8.12 \pm$ & $8.13 \pm$ & $8.99 \pm$ & $6.72 \pm$ & $6.99 \pm$ & $6.90 \pm$ & $24.25 \pm$ & $24.30 \pm$ & $25.46 \pm$ & $12.21 \pm$ & $12.13 \pm$ & $12.12 \pm$ \\
\hline & $0.44^{*}$ & $0.83^{*}$ & $0.78^{*}$ & $0.37 *$ & $0.81^{*}$ & $0.92 *$ & $0.66^{*}$ & $0.93^{*}$ & $0.36^{*}$ & $0.79 *$ & $0.81 *$ & $0.91 *$ \\
\hline \multirow{2}{*}{$\mathrm{Gp}(8)$} & $8.38 \pm$ & $9.95 \pm$ & $10.19 \pm$ & $6.74 \pm$ & $8.68 \pm$ & $9.64 \pm$ & $24.76 \pm$ & $26.73 \pm$ & $26.98 \pm$ & $9.47 \pm$ & $9.66 \pm$ & $9.46 \pm$ \\
\hline & $0.57 *$ & 0.98 & 0.92 & $0.24 *$ & 0.66 & 0.35 & $0.45^{*}$ & 0.84 & 0.57 & 0.64 & 0.51 & 0.27 \\
\hline
\end{tabular}

Increase of liver enzymes may be due to damaging effect of anti-inflammatory on liver [39]. The above mentioned results were supported by previous studies of Valberg [40] who stated that flunixin meglumine induced significant increase in liver enzymes.
Our results demonstrated that pneumonic lambs showed significant increases in liver enzymes (AST, ALT, GGT and ALP), urea and creatinine all over the experimental period. Pneumonia induced elevation in liver enzymes urea and creatinine [27]. Similar results were reported by Kodary and Abdalla 
[41] and El-Shabiny et al. [42] in pneumonic animals.

Healthy lambs received marbofloxacin and flunixin meglumine either alone or together for 5 days displayed significant reduction in serum total protein, albumin, globulin $\alpha, \beta, \gamma$ globulin and significant increase in alpha globulin on $1^{\text {st }}$ and $7^{\text {th }}$ day post injection beside non significant effect in $A / G$ ratio on $1^{\text {st }}$ and $7^{\text {th }}$ day post injection. Reduction in serum total protein and albumin may be due to impaired albumin sythensis by liver due to harmful effect of drugs on hepatic cells [43]. Same change was reported by Elmeleh [30] who stated that marbofloxacin induced significant decrease in total protein, albumin, $\alpha \beta$ and $\gamma$ globulin. These results are reinforced by Ahmed [44] who stated that hypoproteinemia and hypoalbuminemia were evident in levofloxacin treated rats.

Table 4: Effect of marbofloxacin and flunixin meglumine on protein profile in healthy and pneumonic lambs $(\mathbf{n}=5)$

\begin{tabular}{|c|c|c|c|c|c|c|c|c|c|c|c|c|}
\hline \multirow{2}{*}{ Group } & \multicolumn{3}{|c|}{$\begin{array}{l}\text { total protein } \\
\text { (gm /dl) }\end{array}$} & \multicolumn{3}{|c|}{$\begin{array}{l}\text { albumin } \\
\text { (gm /dl) }\end{array}$} & \multicolumn{3}{|c|}{$\begin{array}{l}\text { total globulin } \\
(\mathrm{gm} / \mathrm{dl})\end{array}$} & \multicolumn{3}{|c|}{ A/G ratio } \\
\hline & $\mathbf{1}^{\text {st }} \mathrm{d}$ & $7^{\text {th }} d$ & $14^{\text {th }} \mathrm{d}$ & $\mathbf{1}^{\text {st }} \mathrm{d}$ & $7^{\text {th }} d$ & $14^{\text {th }} \mathrm{d}$ & $1^{\text {st }} d$ & $7^{\text {th }} d$ & $14^{\text {th }} \mathrm{d}$ & $1^{\text {st }} d$ & $7^{\text {th }} d$ & $14^{\text {th }} \mathrm{d}$ \\
\hline \multirow{2}{*}{$\mathrm{Gp}(1)$} & $6.51 \pm$ & $6.46 \pm$ & $6.43 \pm$ & $3.50 \pm$ & $3.45 \pm$ & $3.53 \pm$ & $3.01 \pm$ & $3.01 \pm$ & $1.16 \pm$ & $1.16 \pm$ & $1.15 \pm$ & $1.21 \pm$ \\
\hline & 0.16 & 0.24 & 0.35 & 0.14 & 0.15 & 0.32 & 0.10 & 0.10 & 0.11 & 0.03 & 0.08 & 0.03 \\
\hline \multirow{2}{*}{$\mathrm{Gp}(2)$} & $5.55 \pm$ & $5.25 \pm$ & $6.32 \pm$ & $2.53 \pm$ & $2.52 \pm$ & $3.40 \pm$ & $2.62 \pm$ & $2.73 \pm$ & $2.83 \pm$ & $0.97 \pm$ & $0.92 \pm$ & $1.20 \pm$ \\
\hline & $0.29 *$ & $0.42 *$ & 0.44 & $0.36^{*}$ & $0.32 *$ & 0.31 & $0.07^{*}$ & $0.02 *$ & 0.05 & 0.05 & 0.04 & 0.02 \\
\hline \multirow{2}{*}{$\mathrm{Gp}(3)$} & $5.67 \pm$ & $5.65 \pm$ & $6.12 \pm$ & $2.97 \pm$ & $2.89 \pm$ & $2.88 \pm$ & $2.70 \pm$ & $2.76 \pm$ & $2.74 \pm$ & $1.10 \pm$ & $1.05 \pm$ & $1.05 \pm$ \\
\hline & $0.25^{*}$ & $0.30 *$ & 0.24 & $0.15^{*}$ & $0.13^{*}$ & 0.23 & $0.06^{*}$ & $0.03 *$ & 0.06 & 0.07 & 0.08 & 0.04 \\
\hline \multirow{2}{*}{$\mathrm{Gp}(4)$} & $5.30 \pm$ & $5.43 \pm$ & $5.46 \pm$ & $2.54 \pm$ & $2.64 \pm$ & $2.70 \pm$ & $2.75 \pm$ & $2.70 \pm$ & $2.76 \pm$ & $0.92 \pm$ & $0.98 \pm$ & $0.98 \pm$ \\
\hline & $0.36^{*}$ & $0.29 *$ & 0.14 & $0.21 *$ & $0.31 *$ & 0.21 & $0.05^{*}$ & $0.05^{*}$ & 0.09 & 0.05 & 0.06 & 0.05 \\
\hline \multirow{2}{*}{$\mathrm{Gp}(5)$} & $5.07 \pm$ & $5.13 \pm$ & $5.02 \pm$ & $2.27 \pm$ & $2.32 \pm$ & $2.24 \pm$ & $2.80 \pm$ & $2.80 \pm$ & $2.70 \pm$ & $0.79 \pm$ & $0.83 \pm$ & $0.83 \pm$ \\
\hline & $0.49 *$ & $0.39 *$ & $0.46^{*}$ & $0.43^{*}$ & $0.42 *$ & $0.32 *$ & $0.01 *$ & $0.04^{*}$ & $0.01 *$ & 0.07 & 0.04 & 0.06 \\
\hline \multirow{2}{*}{$\mathrm{Gp}(6)$} & $5.83 \pm$ & $5.40 \pm$ & $6.16 \pm$ & $2.64 \pm$ & $2.92 \pm$ & & $2.74 \pm$ & $2.78 \pm$ & $2.93 \pm$ & $0.96 \pm$ & $1.05 \pm$ & $1.08 \pm$ \\
\hline & $0.49 *$ & 0.16 & $0.33^{*}$ & $0.30 *$ & 0.24 & 0.19 & $0.05^{*}$ & $0.05^{*}$ & 0.09 & 0.08 & 0.09 & 0.07 \\
\hline \multirow{2}{*}{$\mathrm{Gp}(7)$} & $5.28 \pm$ & $5.05 \pm$ & $5.46 \pm$ & $2.62 \pm$ & $2.33 \pm$ & $2.69 \pm$ & $2.66 \pm$ & $7.72 \pm$ & $2.77 \pm$ & $0.98 \pm$ & $0.86 \pm$ & $0.97 \pm$ \\
\hline & $0.49 *$ & $0.42 *$ & $0.23 *$ & $0.36^{*}$ & $0.41 *$ & $0.13^{*}$ & $0.03^{*}$ & $0.06^{*}$ & $0.03 *$ & 0.04 & 0.07 & 0.05 \\
\hline \multirow{2}{*}{$\mathrm{Gp}(8)$} & $5.155 \pm$ & $6.06 \pm$ & $6.21 \pm$ & $2.75 \pm$ & $3.17 \pm$ & $3.36 \pm$ & $2.76 \pm$ & $2.81 \pm$ & $2.95 \pm$ & $0.99 \pm$ & $1.14 \pm$ & $1.14 \pm$ \\
\hline & $0.38^{*}$ & 0.37 & 0.14 & $0.33^{*}$ & 0.27 & 0.14 & $0.02 *$ & 0.04 & 0.06 & 0.06 & 0.07 & 0.09 \\
\hline
\end{tabular}

Close similarity was seen between our finding and those obtained by Carrick et al., [31] they found significant decrease in total protein and gamma globuline and insignificant decrease in total globulin in foal received flunixin meglumine for 5 days. This result may be due to drug toxicity and immunosupressive effect of flunixin meglumine [45]. This observation was previously recorded by Stegelmeir et al., [46] who stated that flunixin meglumine induced hepatocellular damage and decrease total proteins and serum globulin in dog.

Infected lambs with Pasteurella multocida showed significant decrease in total protein, albumin, total globulin, $\alpha, \beta$ globulin beside significant increase in serum $\gamma$ globulins and insignificant effect in $\mathrm{A} / \mathrm{G}$ ratio thought out the experimental period. Reduction in serum total proteins and albumin may be due to destructive effect of bacteria and its toxins on liver cells [47]. Another explanation for hypoprotenemia post bacterial infection come 
from El-Bealawy [48] who reported that hypoprotenemia met with post bacterial infection may be due to amino acid utilization as defense against pathogens. Our data clearly reinforced by Doxey [49] who stated that hypoprotenemia in pneumonic lambs may be due anorexia and inability of the liver to synthesis proteins. Our result was in complete harmony with those reported by Novert [27] who stated that pneumonic calves showed significant increase in serum $\alpha$ and $\gamma$ globulins level. Treatment of infected lambs with $P$. multocida by marbofloxacin and flunixin meglumine either alone or in combination for 5 consecutive days aid in disappear once of clinical symptoms and ameliorates the adverse effects and providing largely returns, erythrogram, total protein, albumin, globulin, liver enzymes urea and creatinine to nearly normal levels. Our results were in accordance with results obtained by Schneider et al., [50] who mentioned that fluoroquinolones had potent antimicrobial activity at very low concentrations when compared with other classes of antimicrobial agents. Also, Rougier et al., [51] mentioned that marbofloxacin was potentially good in treatment of upper respiratory tract disease. Marbofloxacin improve of the clinical signs of respiratory disease [52]. Our finding was in agreement with those obtained by Weingarten [53] stated flunixin is commonly used for relief of pain and control of inflammation and pyrexia associated with diseases of different origin.

Table 5: Effect of marbofloxacin and flunixin meglumine on protein fractions in healthy and pneumonic lambs $(\mathbf{n}=\mathbf{5})$

\begin{tabular}{|c|c|c|c|c|c|c|c|c|c|}
\hline \multirow[b]{2}{*}{ Groups } & \multicolumn{3}{|c|}{ Alpha } & \multicolumn{3}{|c|}{ Beta globulin } & \multicolumn{3}{|c|}{ Gamma } \\
\hline & $\mathbf{1}^{\text {st }} \mathrm{d}$ & $7^{\text {th }} \mathrm{d}$ & $14^{\text {th }} \mathrm{d}$ & $\mathbf{1}^{\text {st }} \mathrm{d}$ & $7^{\text {th }} \mathrm{d}$ & $14^{\text {th }} \mathrm{d}$ & $\mathbf{1}^{\text {st }} \mathrm{d}$ & $7^{\text {th }} d$ & $14^{\text {th }} \mathrm{d}$ \\
\hline $\mathrm{Gp}(1)$ & $0.97 \pm 0.03$ & $0.96 \pm 0.04$ & $0.91 \pm 0.04$ & $0.99 \pm 0.04$ & $0.97 \pm 0.06$ & $0.96 \pm 0.02$ & $1.05 \pm 0.06$ & $1.08 \pm 0.04$ & $1.03 \pm 0.05$ \\
\hline $\mathrm{Gp}(2)$ & $1.07 \pm 0.03^{*}$ & $1.09 \pm 0.06$ & $0.92 \pm 0.05$ & $0.76 \pm 0.03 *$ & $0.74 \pm 0.08$ & $0.93 \pm 0.08$ & $0.79 \pm 0.06^{*}$ & $0.90 \pm 0.04 *$ & $0.95 \pm 0.09$ \\
\hline $\mathrm{Gp}(3)$ & $1.06 \pm 0.02 *$ & $1.04 \pm 0.04$ & $0.87 \pm 0.06$ & $0.83 \pm 0.03 *$ & $0.87 \pm 0.04$ & $0.84 \pm 0.06$ & $0.81 \pm 0.08 *$ & $0.85 \pm 0.06 *$ & $1.01 \pm 0.06$ \\
\hline $\mathrm{Gp}(4)$ & $1.07 \pm 0.02 *$ & $0.99 \pm 0.05$ & $0.93 \pm 0.08$ & $0.88 \pm 0.03 *$ & $0.85 \pm 0.07$ & $0.82 \pm 0.07$ & $0.80 \pm 0.09 *$ & $0.86 \pm 0.06^{*}$ & $1.01 \pm 0.08$ \\
\hline $\mathrm{Gp}(5)$ & $0.89 \pm 0.01 *$ & $0.85 \pm 0.02 *$ & $0.93 \pm 0.01 *$ & $0.82 \pm 0.06 * 0$ & $0.89 \pm 0.04 *$ & $0.81 \pm 0.01 *$ & $1.19 \pm 0.02 *$ & $1.17 \pm 0.02 * 1$ & $1.14 \pm 0.05^{*}$ \\
\hline $\mathrm{Gp}(6)$ & $0.92 \pm 0.05$ & $0.91 \pm 0.05$ & $0.91 \pm 0.06$ & $0.81 \pm 0.05 * 0$ & $0.85 \pm 0.03 *$ & $0.99 \pm 0.05$ & $1.04 \pm 0.05$ & $1.02 \pm 0.04$ & $1.02 \pm 0.09$ \\
\hline $\mathrm{Gp}(7)$ & $0.87 \pm 0.03^{*}$ & $086 \pm 0.02 *$ & $0.86 \pm 0.04^{*}$ & $0.80 \pm 0.04 * 0$ & $0.83 \pm 0.04 *$ & $0.90 \pm 0.01 *$ & $0.99 \pm 0.10$ & $1.03 \pm 0.091$ & $1.01 \pm 0.08^{*}$ \\
\hline $\mathrm{Gp}(8)$ & $0.92 \pm 0.08$ & $0.91 \pm 0.05$ & $0.96 \pm 0.04$ & $0.84 \pm 0.06^{*}$ & $0.85 \pm 0.08$ & $0.96 \pm 0.07$ & $1.04 \pm 0.09$ & $1.03 \pm 0.14$ & $1.03 \pm 0.18$ \\
\hline
\end{tabular}

Significant at $\mathrm{p}<0.05 \quad * *$ Significant at $\mathrm{p}<0.01 *$

\section{Conclusion}

It could be concluded that, pasteurellosis infection in lambs resulted in change in hemato-biochemical parameters which lead to economic losses in lambs. Marbofloxacin and flunixin meglumine either alone or together for 5 consecutive days treatment helped in controlling of the infection by P.multocida.

\section{Conflict of interest}

The authors declare no conflict of interest.

\section{References}

[1] Callan, R.; Gunch, T. and Mock, R. (1991): Development of pneumonia in sheep after exposure to a flock of exotic wild and domestic sheep. J Am Vet Ned. Ass. 198 (6)152-155 .

[2] Rimler, R. and Rhoades, K. (1989): Pasteurella multocida. In Adlan, C.; Rutter, J, Ed Pasteurella and Pasteurellosis. London, Academic Press, 37-73. 
[3] Gilmour, N. and Angus, K. (1993): Pasteurellosis In: Diseases of Sheep; Black well Scientific Publications, Oxiford., 3-8.

[4] Thomas E, Caldow G, and Davot J(2001): efficacy and tolerance of marbofloxacin in treatment of bovine respiratory disease. J Vet Pharm Ther. 24 (5)53-58.

[5] Meunier, D.; Acar, J. and Vall, M. (2004): survey of susceptibility to marbofloxacin of bovine pathogenic strains from eight European countries. Inter $\mathbf{J}$ of Anti Ag, 24:70.

[6] Abd El. Aliem, Nabila (1999): Immunotoxic effect of flunixin meglumine and isoflupredone acetate in rabbits. J Egypt Vet Med Ass 59:61-87.

[7] Cruickshank R, Duguid J, Marmin B and Swain R (1975): Medical Microbiology. (2)Practice of Med Microb. $12^{\text {th }}$ Ed Churchill Livingstone, London.

[8] Okerman L, Spanoghe L and De Bruycker R (1979): expermental infection of mice with p. milt strain isolated from rabbits.J. Comp. Path.89:51-55.

[9] Quinn P, Markery B , Carter M , Donnelly W and Leonard F(2002): Veterinary Microbiology and Microbial Diseases. Block well Sci Ltd.

[10] Anadon, A; Martinez M and Castelna, V (2002): Pharmacokinetic and tissue residues for marbofloxacin in chicken. Am. J.Vet. Res 63(7) 27-33 .

[11] Jain, N.C. (1986): Schalm's Veterinary Hematology. 4th Ed, Lea and Fibiger, philadelphia, U.S. A. PP. 834.

[12] Doumas, B.; Carter, R.; Peers, T. and Schaffier, R. (1981):A candidate reference method for determination total protein serum. Clin Chem 27, 64.

[13] Henry, R.; Cannon, D. and Winkelman, J. (1974): Clinical Chemistry: Principals and Techniques p. 437-440, Harper and Row, Hagrstown.

[14] Reitman, S. and Frankel, S. (1957): Calorimetric determination of transaminases activity, Am. J. Clin. Path. (28)56.
[15] Kaplan, L and Pesce, A (1992): Clinical Chemistry $2^{\text {nd }}$ Ed St. Louis,.CV Mosby Comp.

[16] John, D. (1982): Clinical laboratory mothed for determination of alkaline phosphatase. 9th Ed. 580-581.

[17] Fawcet, J. and Scott, J. (1960): Determination of urea. J. Clin. Path. (13) 156.

[18] Husdan H and Rapoport, A (1968): Estimation of creatinin Clin Chem (14) 22.

[19 ]Petrie A and Watson P (1999): Statistics for Veterinary and Animal Science 1st Ed. 90-99, the Blackwell Science LTd, United Kingdom.

[20] Abdalla O. \& Emam .E. (2005): Effect of marbofloxacin and isoflueredone acetate as therapy of pneumonia associated with pasteurela multocida in lambs. $4^{\text {th }}$ Scentific Conf. of Fac of vet. Med. Mansoura Univ. 283-301.

[21]Morad, M; El-Amrousi, S. and El. Allawy, T. (1980): Experim- ental studies of some strains of P. multocida from different animals. Assiut Vet. Med. J.,(7)342-350.

[22]El-Dahshan E and Elham I. (2006): bacterial agents isolated from pneumonic sheep. $8^{\text {th }}$ Sci. Vet. Med. Zag. , Conf.

[23] Valle M; Schneider, M and Woehrle F (2012): Pharmacokinetic and pharmacodyna- mic of marbofloxacin administered as a single injection for the treatment of bovine respiratory disease. $\mathbf{J}$ Vet Pharm Ther.; 35 (6)19-28.

[24]Zeitoun, A. (2001): Clinical study of pneumonic mycoplasmosis and pasturellosis in commercial sheep flock. Assiut, Vet Med. J. 45: 89 162-17.

[25] Hussein, E, Alam, T and Masoud, E (2006): studies on clinical, haematobiochemical changes in pneumonic lamb with trials of treatment. Mansoura Vet Med. J 8 (1) 81-97

[26] Ali M., Ibrahim I. and Zaid M. (2017): Green Tea as a Supportive Treatment for 
Respiratory Disorders in Calves Alexandria J of Vet Sci ; 52(1) 118-124.

[27] Novert, M. (2004): Bacteriological and mycoplasmal studies on lung infections in calves. J Egypt Vet Med. Ass.62, 4:89-94.

[28] Axel, D. and Itamar, S. (2003): Immunomodulatory effects of quinolones. Lancet Infect Dis 3(6) 359371.

[29] Yeates, F. and March, D. (1980): adrenal cortex. in medical physiology(54) 85.

[30]Elmeleh, A. A. (2008): some pharmacodynamic effects of marbofloxacin. MVSc Thesis (pharmacology) Fac. of Vet Med Benha Univ.

[31]Carrick, J., Popich, M. and Townsend, H. (1989): Clinical and pathological effects of flunixin mglumine in neonatal foals.Can.F Vet Res. 53 (2) 95- 101.

[32]McIlwraith, C.; Frisbie, D. and; Kawcak, C. (2001): Non steroidal AntiInflammatory Drugs. Proc. AAEP (47): 182-187.

[33] Abdullah F, Osman A, Adamu L. Saad M, Saharee A (2013): Haematological and Biochemical Alterations in Calves Following Infection with Pasteurella multocida Type B: 2, Bacterial Lipopolysaccharide and Outer Membrane Protein Immunogens . Asian $\mathrm{J}$ of Anim and Vet Adv, 8: 806-813.

[34] Dagmar, J.; Muhsin, O. and Ntondo, B. (2002): Production and characterizeation E coli enterohemolysin and structure effects of erythrocyte membranes. Cell Biolo Inter 26(2)75-86.

[35]Salh, L. and El. Bably, M. (1998): Hygienic studies for control of pneumonia in buffaloe calves with special refference to its ClincoLaboratory diagnosis. $8^{\text {th }}$ Sci, Fact, Vet. Med. Assiut Univ. Egypt 173-187.

[36]Clark, L.; Deborah, V.; and Saad, A. (2001): Profiles of hepatic and dysrhythmic cardiovascular events post use fluoroquinolone: Experience from large cohorts from drug safety research unit prescription monitoring database. Drug Safety 24:43-54.

[37]Kaplan. M. (1987): Primary biliary cirrhosis. N. Engl. J. Med.316 (9) 21-28.

[38]Hanafy, A. (1993): Some adverse effects of norfloxacin in male rats. Thesis presented to Fac. of Vet. Med., Edfina, Alex. Univ. for the degree of MVSc.

[39]Er, A., Dik, B., and Cetin, G. (2013):Cardiac safety of diclofenac at a single dose in ram. The Scientific World J 2013: 808731 .

[40]Valberg, S. (2002) A review of the diagnosis and treatment of rhabdomyolysis in foals. American Asso of Equine 48,17-21.

[41]Kodary, R. and Abdalla, O.(2001): Evaluation of tilmicosin as a treatment for pneumonia in ewes. Beni- Suef Vet.Med, J, 11 (28)53-63.

[42]El-Shabiny, M. Laila; Agag, B. and ElEbeedy, A. (2001): Contagious caprine pleuropneumonia in goats. 6th Soci for Cattle Dis, , Assuit, Egypt.

[43]Kaneko, J. (1989): Clinical biochemistry of domestic animals $4^{\text {th }}$ Ed., Academic.

[44]Ahmed, A (2017): protective effect of some antioxidants on adverse effects of levofloxacin in albino rats. M Sc. Thesis Fac. Vet. Med. Zag Univ.

[45]Cheng, Z.; Nolan, A. and McKellar, Q. (1998): Measurement of cyclooxygenase inhibition in vivo of two nonsteroidal antiinflammatory in sheep. Inflam. 22:53-66.

[46]Stegelmeir B; Bottoms, G and Reed, W (1988): Effect of Flunixin meglumine in dogs post experimentally induced entrotoxaemia. Cornel Vet. 78: 221230.

[47]Radostits, O, Gay, C, Hinchcliff, K and Constable, P. (2007): Veterinary Medicine. A textbook of diseases of cattle, sheep and horses, W.B. Saunders Co.68-77.

[48]El-Bealawy, M. (2003): Haematological and biochemical studies on pneumonia in 
new born calves. Egypt. J Agric. Res. 81(1) 23.

[49 ]Doxey, D (1971): Veterinary Clinical Pathology. $1^{\text {st }}$ Ed. Bailliere tindal, London .

[50] Schneider, M; Thomas, V and Deleforge, J (1996): marbofloxacin Pharmacokinetics in dogs after oral administration. J Vet Pharm. Ther. 19, 56-61.

[51] Rougier S; Galand D; and Vall, M (2006): Epidemology and susceptibility pathoge- nic bacteria responsible for respiratory tract infections in rabbits. Vet Micr.; 9(3)54-66.

[52] Waxman, S.; Vicente, M. and Andres, M. (2001): marbofloxacin Pharmaco-kinetic after I/V and I/M injection in adult goats. J. Vet. Pharmac. 20 (6) 75-78.

[53] Weingarten, A. J. (2009): Mechanisms of action and role of antiinflammatory in treatment of bovine respiratory disease. Proceedings of symposium on best practices in BRD treatment:. European Buiatrics. Marseille, pp 6-15.

\section{الملخص العربي}

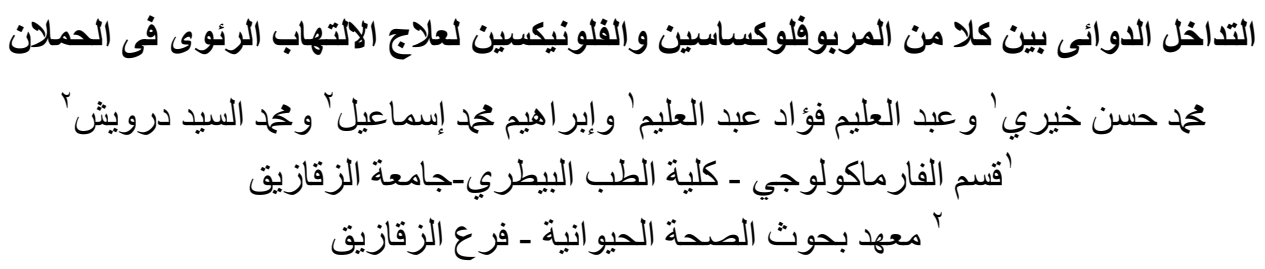

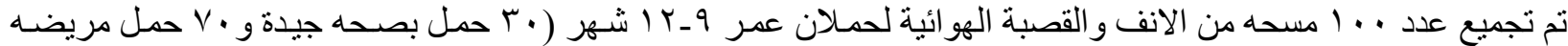

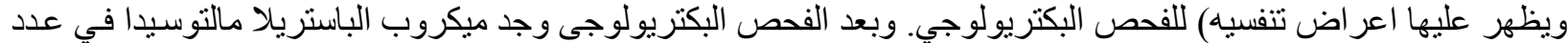

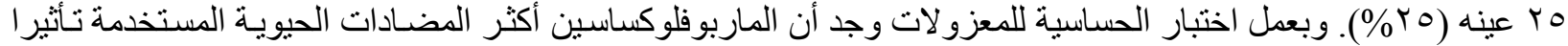

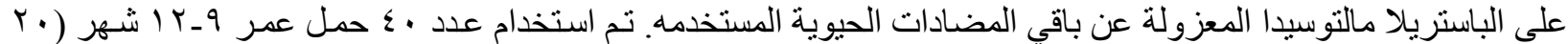

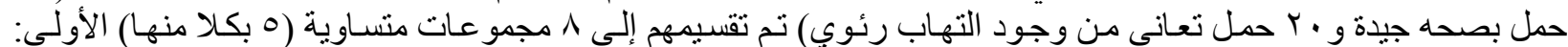

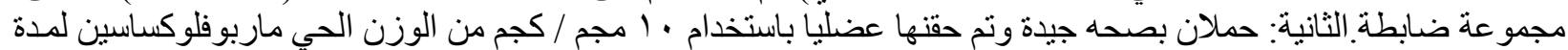

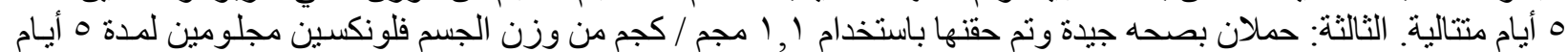

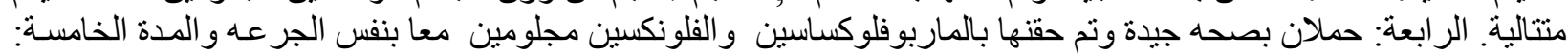

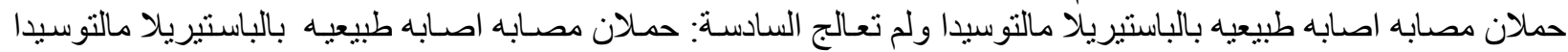

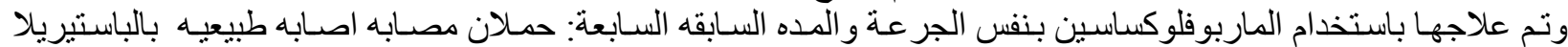

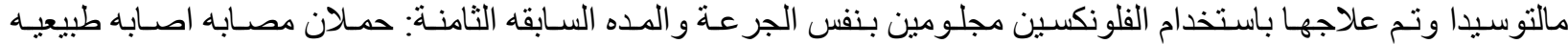

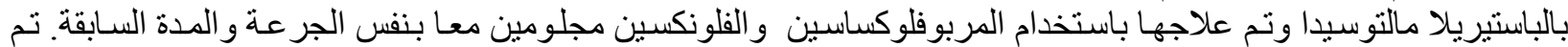

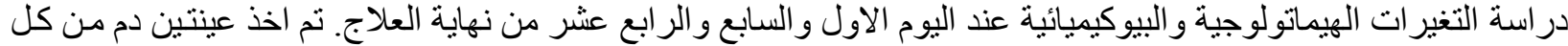

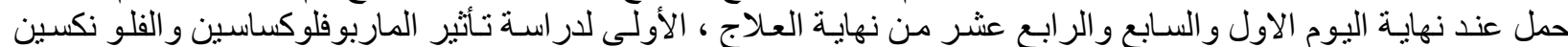

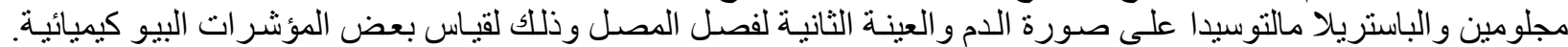

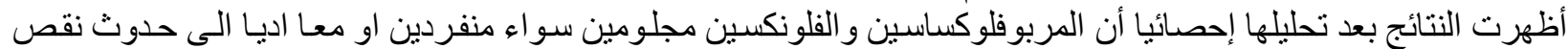

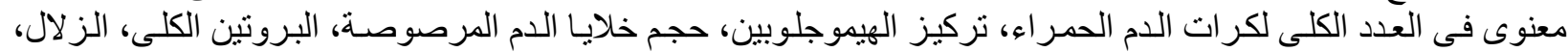

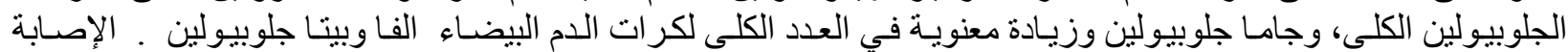

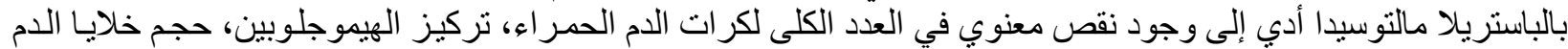

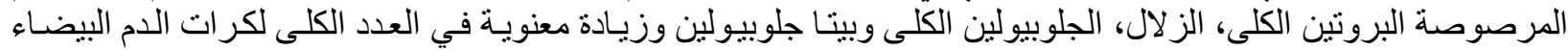

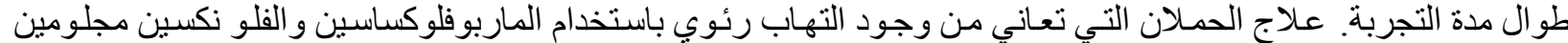

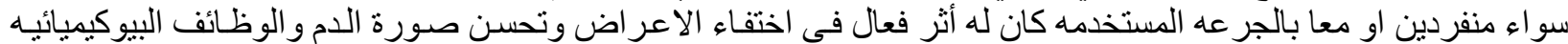

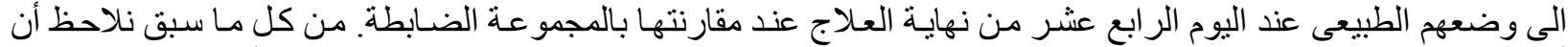

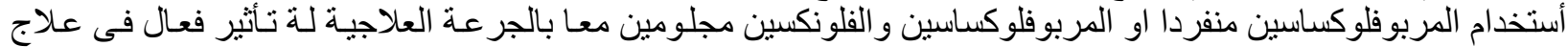

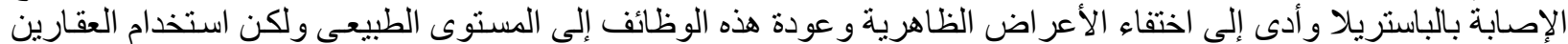

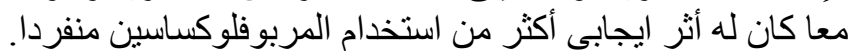

